\title{
Improvement of the Quality of the Local Beer «Tchukoutou» by Addition of two Antioxidant plants: Ocimum gratissimum and Vernonia amygdalina
}

\author{
AWÈDÉOU BAKPO*, AGBEKONYI KOKOU AGBODAN, KWAMI LUMO AWAGA, \\ CYNTHIA ADJO KOUAKOU, EYAWĖDEOU YELEGUE and KOFFI JONDO
}

Laboratory of Process Engineering and Natural Resources (LAGEPREN), Togo.

*Corresponding author E-mail: bakpocharlote@gmail.com; akatologo@gmail.com

http://dx.doi.org/10.13005/ojc/370508

(Received: August 20, 2021; Accepted: October 17, 2021)

\begin{abstract}
Tchoukoutou are the most widely consumed alcoholic beverages in Africa. However, several constraints undermine this sector of activity. The overall objective of this study is to improve the quality and stability of "Tchoukoutou" by adding leaves of Ocimum gratissimum and Vernonia amygdalina. Two methods of evaluating the alcoholic degree: densimetry and refractometry were used to find the physic and chemical characteristics. From the results obtained, it appears that the red sorghum (Kadag) gives the best organoleptic quality of beers. The addition of the leaves of $O$. gratissimum and $V$. amygdalina followed by anaerobic fermentation allowed the preservation and stability of «Tchoukoutou» for at least 10 days at room temperature with a bitterness similar to hops; an alcohol content of $8.87 \% \mathrm{vol}$, a pH of 4.37 and a Brix degree of $14^{\circ}$ Brix. In conclusion, the anaerobic fermentation of the must and the addition of the leaves of $O$. gratissimum and $V$. amygdalina contribute to the improvement of the conservation quality and stability of the Chukutu.
\end{abstract}

Keywords: Tchoukoutou, Fermentation, Stabilization, Alcohol level,

$$
\text { O. gratissimum, V. amygdalina. }
$$

\section{INTRODUCTION}

Tchoukoutou are traditional beers made with sorghum and other cereals such as millet or maize ${ }^{1}$. In Togo, it exists different types of this beer, depending on the ethnic groups of the north. Thus, we distinguish: the "Kablè-Missine», produced by the Kabyè; the "Losso-Missine", produced by the Nawdemba and the "Tchakpa-Missine" or "Tchakpalo", produced by the Moba ${ }^{2}$. In the production technology of Tchoukoutou, we note the double fermentation: a lactic fermentation that confers a sour taste and an alcoholic fermentation initiated by adding to the sweet must part of the previous infusion or dried yeast harvested from the previous drink without knowing the nature of the ferment ${ }^{3,4,5}$. Over time, production conditions have not changed. The manufacturing process suffers from a crucial lack of precision measurement instruments and good hygiene practices ${ }^{6}$. Brewers face production and conservation challenges. The quality of beer varies from one site to another and this variation

This is an Open Access article licensed under a Creative Commons license: Attribution 4.0 International (CC- BY). Published by Oriental Scientific Publishing Company @ 2018

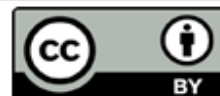


is noticeable. The resulting beer is unstable and its organoleptic characteristics continue to change, and in $72 \mathrm{~h}$ it becomes too acidic to be consumed also within the same production site when it comes to production prior to that of the day ${ }^{7}$. The short shelf life of this traditional beer limits its consumption to less than one day of production. It is therefore important to improve Tchoukoutou's production and conservation technology in order to preserve its nutritional and market qualities and reduce the risk of food poisoning. Antimicrobial chemicals have been widely used as food preservatives, however, their use increases the risk of toxic residues in products ${ }^{8}$.

To improve the conservation and stability of sorghum beer, some researchers in the West African sub-region have used natural antioxidants to conserve sorghum beer. The purpose of this study is to help improve the conservation and stabilization of Chukutu by adding leaves of Ocimum gratissimum and Vernonia amygdalina. It will be more specifically to produce beer according to traditional technology in order to identify problems of instability; optimize the production technology by adding the leaves of the Ocimum gratissimum and Vernonia amygdalina to obtain a stable product and compare two techniques of evaluation of the alcoholic degree: densimetry and refractometry to determine the most practical and easy-to-use method for brewers.

\section{MATERIALS AND METHODS}

\section{Plant material}

The sorghum varieties used are selected and grown in the savannah region: white sorghum (Sorvato 1); red sorghum (Kadag); mixture (Sorvato 28 and Jerry). They were collected at the Togolese Institute for Agricultural Research (ITRA-Togo). The leaves of Ocimum gratissimum (Esro en ewe) and Vernonia amygdalina (Aloma en ewe) were purchased at the Agoè Assi yeye market, washed and dried in the laboratory.

\section{Methods of preparing beer \\ Traditional Tchoukoutou Preparation process}

Two varieties of sorghum have been used: red sorghum (Kadag) and white sorghum (Sorvato 1) for the preparation following the traditional process steps of the brewers in Togo whose major steps are: malting, brewing and fermentation.
An $800 \mathrm{~g}$ mass of sorghum is soaked in water for 18 hours. Then the hydrated grains are washed. After $24 \mathrm{~h}$ a second wash is carried out and the seeds in germination are spread out in a thin carpet cabinet and covered with a cotton cloth. After $72 \mathrm{~h}$ for $12 \mathrm{~h}$ for the Kablè-missine in the laboratory and $48 \mathrm{~h}$ in the sun for Tchakpalo. The resulting malt is then ground into flour for grinding. The deposit is pre-cooked for 2 hours. After filtration, the sampled part is added to the filtrate and spontaneous lactic fermentation begins. After 12 to $15 \mathrm{~h}$ of lactic fermentation, the resulting sour must is brought to a boil for $2 \mathrm{~h}$ and $30 \mathrm{~min}$ to concentrate and sterilize the must. Then cooled down to $30^{\circ} \mathrm{C}$, then seeded with the brewer's yeast (germination, sprouts are dried Saccharomyces cerevisiæ), the local beer Chukoutou is obtained after $12 \mathrm{~h}$ of alcoholic fermentation.

\section{Optimization and Stabilization Process Laboratory process}

Sorghum is malted under the same conditions as before. After grinding the resulting flour is packed at temperature levels at time intervals: $50-55^{\circ} \mathrm{C}$ for $1 \mathrm{~h} ; 55-65^{\circ} \mathrm{C}$ for $30 \min 65-70-80^{\circ} \mathrm{C}$ for 1 hours. Then the must is filtered and brought to a boil for $1 \mathrm{~h} \mathrm{30-2} \mathrm{h}$ of time. The dry leaves of $O$. gratissimum and $V$. amygdalina are added to the must during boiling instead of hops. The must is cooled after cooking and seeded with $S$. cerevisiae anaerobically for 7 days.

\section{Traditional Enhanced Process}

The must is obtained under the same conditions as the traditional process. A quantity of $5 \mathrm{~g}$ of dry leaves of $O$. gratissimum and $1 \mathrm{~g}$ of $V$. amygdalina are added to the must during boiling. The must is cooled after cooking and seeded with $S$. cerevisiae anaerobically for 7 days. After fermentation, the beer obtained is sampled to test the organoleptic and physico-chemical characteristics.

\section{Organoleptic characteristics}

The organoleptic characteristics determined are: taste, aroma and colour of the samples. This assessment was made through a panel of seven (7) tasters composed of the consumers and those which is not consumers of this beer. 
Physic and chemical characteristics of beers Determination of alcoholic strength of beer

The alcohol content of the beers was determined by the densimetric and refractometry method.

\section{Densimetry}

The density of the beers was measured by a portable density meter calibrated for a temperature of $20^{\circ} \mathrm{C}$. Graduated generally in specific density (SG) from 1000 to 1100 or plato degree.

By measuring the density of the must before and after fermentation, it was possible to estimate the alcohol content of a fermented and alcoholic drink. The must obtained from sorghum contains sugars and fermentable sugars are converted into alcohol and carbon dioxide $\left(\mathrm{CO}_{2}\right)$. The other sugars will participate in the formation of the beer body. By comparing the initial and final densities, we can calculate the alcohol mass in the tank. By making an approximation that the sugar involved in the reaction is glucose, the balance equation is as follows:

$\mathrm{C}_{6} \mathrm{H}_{12} \mathrm{O}_{6} \rightarrow 2 \mathrm{CH}_{3} \mathrm{CH}_{2} \mathrm{OH}+2 \mathrm{CO}_{2}$

From the alcohol formation balance equation, the ratio of the weight of the alcohol produced to that of the weight of carbon dioxide is calculated as:

$\frac{\text { Weight of the alcohol }}{\text { Weight of carbon dioxide }}=\frac{\text { Molar mass of Alcohol }(\mathrm{g} / \mathrm{mol})}{\text { Molar mass of } \mathrm{CO}_{2}\left(\frac{\mathrm{g}}{\mathrm{mol}}\right)}$

This ratio is a constant equal to $1,04678 \approx 1,05$. [Initial Density $]-[$ Final Density $]=$ Attenuation [Alcohol mass $(\mathrm{g})]=\left[\right.$ mass of $\left.\mathrm{CO}_{2}(\mathrm{~g})\right] \times 1,05$ [Percentage by mass of alcohol (\%.mass)] = Alcohol weight (g) x100

$[$ Percent by volume $(\%$.vol $)]=\frac{\text { Percentage by mass }(\mathrm{g})}{\text { Density of } \operatorname{Alcohol}\left(\frac{\mathrm{g}}{\mathrm{l}}\right)}$

The BIRRAPPS software version 2.0 pilsener corrects the density of the must according to the temperature.

\section{Refractometry}

The total soluble matter rate in Brix $\left({ }^{\circ} \mathrm{Brix}\right)$ was measured by a portable ATC refractometer graduated from 0 to $32^{\circ}$ Brix precision 0.01 . The device was calibrated using distilled water at $20^{\circ} \mathrm{C}$. Two to three drops of the solution are placed on the refractometer prism and directed to a light source for reading. \pm

$\%$ Brix $=\frac{\text { Weight of the alcohol }(\mathrm{g})}{\text { Weight of the mixture }(\mathrm{g})} \times 100$

After measuring the Brix degree, the sugar content and the corresponding specific density are found using the conversion table and the alcohol content is calculated by the Brewing calculator (SD 1.04).

\section{pH measurement}

The $\mathrm{pH}$ of the drinks was measured by an electronic $\mathrm{pH}$ meter of type MP522 of precision 0,002 $\mathrm{pH}$, previously calibrated.

\section{Data Processing}

The values of the alcohol content by refractometry were calculated by the software brewing calculator version: 2.2.5 of standard deviation 1.04. The curves and graphs were created with the software Origine ${ }^{8}$.

\section{RESULTS AND DISCUSSION}

\section{Traditional Procedure}

\section{Density obtained by the density meter}

The density before fermentation $\mathrm{DI}=1075$ g/L for white sorghum must (Sorvato 1) and 1076 $\mathrm{g} / \mathrm{L}$ for red sorghum (Kadag). The densities obtained after fermentation are recorded in Tables I and II. These results show that the density decreases during fermentation and stabilizes from the fourth day for Kadag beer and from the fifth day for Sorvato 1 beer with appearance of mould and acid taste.

Table I: Density of Sorvato1 beer during fermentation

\begin{tabular}{lccccccc}
\hline Duration of fermentation (days) & 1 & 2 & 3 & 4 & 5 & 6 & 7 \\
\hline Density (g/L) & 1032 & 1030 & 1027 & 1024 & 1022 & 1022 & 1022 \\
\hline & Table II: Density of Kadag beer during fermentation & 1022 \\
\hline Duration of fermentation (days) & 1 & 2 & 3 & 4 & 5 & 6 & 7 \\
\hline Density $(\mathrm{g} / \mathrm{l})$ & 1026 & 1022 & 1021 & 1020 & 1019 & 1019 & 1019 \\
\hline
\end{tabular}




\section{Determination of Alcoholic Strength Density method}

The alcohol content of red sorghum beer (Kadag) is $7.48 \%$. vol and $6.84 \%$. vol for white sorghum (Sorvato1). The results show that Kadag's beer is more alcoholic. Fig. 1 illustrates the evolution of the alcoholic strength of beers during fermentation. It can be seen that Kadag's beer quickly stabilized compared to that of Sorvato 1.

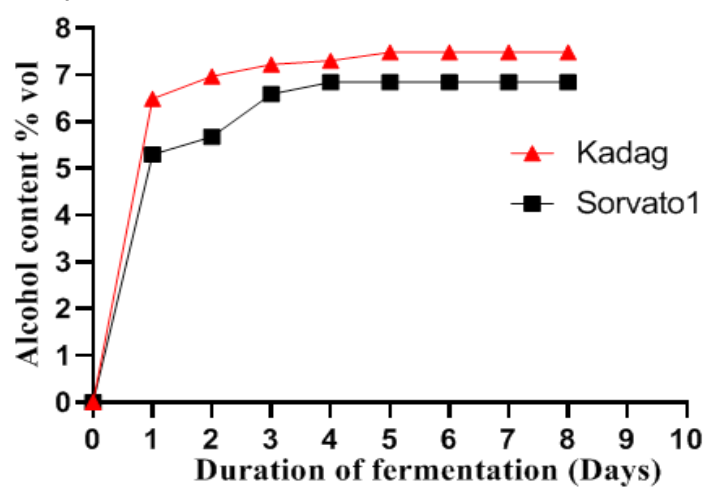

Fig. 1. Variation in alcoholic strength of Sorvato1 and Kadag beers as a function of fermentation time

The study of the evolution of the alcoholic level of beer during aerobic alcoholic fermentation (Fig. 1) has shown that the alcohol level increases during the first three days of fermentation and stabilizes from the fourth day. These results are similar to those of Novidzro and et al., (2019) ${ }^{10}$. Sorghum beer undergoes rapid fermentation and contact with bacteria and oxygen in the air, which deteriorates the quality and preservation of beer.

\section{Sorghum Beer Optimization and Stabilization Processes \\ Organoleptic characteristics of beers}

After one week of anaerobic fermentation, the organoleptic characteristics of taste, aroma, appearance and other were evaluated by a tasting panel and the results are recorded in Tables III and IV.

The evaluation of the organoleptic characteristics of the beers shows that the colour of the beer depends on the type of sorghum used and the beers have the aroma of $O$. gratissimum with a bitterness of $V$. amygdalina similar to hops. The beers obtained by the laboratory method are more acidic and less alcoholic with an unpleasant aroma. Sorghum Sorvato1 produces more alcohol but gives a sour taste. Kadag's beers were more popular. The beers obtained with $5 \mathrm{~g}$ of $V$. amygdalina had a great bitterness and the quantity was reduced to $1 \mathrm{~g}$ to have a slight bitterness.

\section{Laboratory process}

Traditional Enhanced Process

Table III: Organoleptic characteristics of beers obtained by laboratory process

\begin{tabular}{|c|c|c|c|c|c|c|c|}
\hline $\begin{array}{l}\text { Type of } \\
\text { sorghum }\end{array}$ & $\begin{array}{l}\text { Amount of } \\
\text { sorghum (g) }\end{array}$ & $\begin{array}{l}\text { Type of } \\
\text { drying }\end{array}$ & $\begin{array}{c}\text { Amount of } \\
\text { O. gratissimum }(\mathrm{g})\end{array}$ & $\begin{array}{c}\text { Amount of } \\
\text { V. amygdalina }(\mathrm{g})\end{array}$ & $\begin{array}{c}\text { Quantity of } \\
\text { beer obtained (I) }\end{array}$ & $\begin{array}{c}\text { Alcohol } \\
\text { content \%.vol }\end{array}$ & $\begin{array}{l}\text { Organoleptic } \\
\text { characteristics }\end{array}$ \\
\hline \multirow[t]{2}{*}{ Kadag } & 500 & Roasted & 5 & 5 & 1 & - & $\begin{array}{l}\text { The beer was very } \\
\text { heavy: bad }\end{array}$ \\
\hline & & Sun & 5 & 1 & 2 & 3.07 & $\begin{array}{l}\text { aroma and sour } \\
\text { taste not good }\end{array}$ \\
\hline S28 & 500 & Sun & 5 & 1 & 2 & 3.10 & Not good \\
\hline Jerry & & Sun & 5 & 1 & 2 & 2.44 & $\begin{array}{l}\text { aroma and taste } \\
\text { not good }\end{array}$ \\
\hline $\begin{array}{l}\text { S28 \& } \\
\text { Jerry }\end{array}$ & 500 & Sun & 3 & 1 & 2 & 4.10 & Slightly sour \\
\hline $\mathrm{S}_{1}$ & 500 & Sun & 3 & 2 & 2 & 5.51 & Good \\
\hline
\end{tabular}

Table IV: Organoleptic characteristics of beers obtained by the traditional improved method

\begin{tabular}{|c|c|c|c|c|c|c|c|}
\hline $\begin{array}{l}\text { Type of } \\
\text { sorghum }\end{array}$ & $\begin{array}{l}\text { Amount of } \\
\text { sorghum (g) }\end{array}$ & $\begin{array}{l}\text { Type of } \\
\text { drying }\end{array}$ & $\begin{array}{c}\text { Amount of } \\
\text { O. gratissimum }(\mathrm{g})\end{array}$ & $\begin{array}{c}\text { Amount of } \\
\text { V. amygdalina (g) }\end{array}$ & $\begin{array}{c}\text { Quantity of } \\
\text { beer obtained (I) }\end{array}$ & $\begin{array}{c}\text { Alcohol } \\
\text { content \%.vol }\end{array}$ & $\begin{array}{l}\text { Organoleptic } \\
\text { characteristics }\end{array}$ \\
\hline \multirow[t]{2}{*}{ Kadag } & 500 & Shadow $12 \mathrm{~h}$ & 5 & 5 & 2 & 6.59 & $\begin{array}{l}\text { Good; slightly } \\
\text { bitter taste }\end{array}$ \\
\hline & 500 & Sun $48 \mathrm{~h}$ & 5 & 1 & 2,5 & 4.86 & Very Good \\
\hline S28 & 500 & Sun $48 \mathrm{~h}$ & 5 & 1 & 2 & & Pretty good \\
\hline \multirow[t]{2}{*}{ Jerry } & 500 & Shadow & 5 & 1 & 2 & 6.46 & \multirow{3}{*}{$\begin{array}{l}\text { Pretty good } \\
\text { Pretty good } \\
\text { Good }\end{array}$} \\
\hline & 500 & Sun $48 \mathrm{~h}$ & 5 & 1 & 2 & 5.10 & \\
\hline $\begin{array}{l}\text { S28 \& } \\
\text { Jerry }\end{array}$ & 500 & Sun & 5 & 1 & 2 & 4.58 & \\
\hline \multirow[t]{2}{*}{$\mathrm{S}_{1}$} & 500 & Shadow & 3 & 2 & 2 & 8.87 & \multirow{2}{*}{$\begin{array}{l}\text { Sour and not very } \\
\text { good aroma } \\
\text { Good and aroma } \\
\text { not good }\end{array}$} \\
\hline & & Sun & 3 & 2 & 2 & 6.39 & \\
\hline
\end{tabular}


The study of the evolution of fermentation parameters during the preparation of beer shows that the quality of beer depends not only on the type of ferment used but also on the conditions of fermentation. The beer obtained by the addition of the leaves of $O$. gratissimum and $V$. amygdalina followed by the anaerobic fermentation with S.cerevisiae had a higher alcoholic degree and a longer shelf life than that obtained by the aerobic fermentation without the addition of $O$. gratissimum and $V$. amygdalina. Indeed, the work of ${ }^{5}$ on the variability of the physico-chemical properties of fermented must during the preparation of chapalo, indicate that producers use ferments whose quality is often not assured. The fermentation is carried out in aerobic at room temperature $\left(25-30^{\circ} \mathrm{C}\right)$ with the consequence of the proliferation of the yeast charge. Which limits the shelf life of this beer. However, anaerobic fermentation with S.cerevisiae has improved the quality of this beer. These antioxidant plants have a conservative stabilizing effect on the quality of Tchoukoutou. Kadag beer is more popular than other sorghum beer. Kadag is the best sorghum for the preparation of Tchoukoutou.

In summary, red sorghum (Kadag) and the addition of $5 \mathrm{~g}$ of dry leaves of Ocimum gratissimum and $1 \mathrm{~g}$ of Vernonia amygdalina give the best organoleptic qualities of Tchoukoutou beer.

\section{Physic and chemical characteristics of beers}

The results (Tables V, IV and VII) show that sorghum Sorvato 1 produces more alcohol than other sorghum regardless of the brewing process (6.98\%. flight for the laboratory process; $8,87 \%$. vol for improved Kablè-missine and 6,39\%.vol for improved Tchakpalo). The densities, the degree Brix and the $\mathrm{pH}$ of the musts are higher than those of the corresponding beers. Analysis of the results of Tables V, VI and VII shows that the density, Brix and alcohol content of musts and beers vary not only according to the sorghum varieties used but also according to the brewing methods ${ }^{11}$. Antioxidant plants make it possible to obtain beers with higher physic and chemical characteristics. These plants have a beneficial effect on the quality of beer and has the highest physic and chemical characteristics but those of Kadag are most appreciated on.

\section{Density Method}

The density of the musts was measured by the density meter and the corrections were made with the Birrapps software. The results are summarized in V, VI and VII.

\section{Beer obtained by laboratory process Improved of traditional beer Enhanced Kablè-missine Improved Tchakpalo}

Table V: Alcohol content of laboratory-produced beers

\begin{tabular}{|c|c|c|c|c|c|c|c|}
\hline Type of sorghum & Initial density $(\mathrm{g} / \mathrm{L})$ & \multicolumn{2}{|c|}{ Final density (g/L) } & $D(g / L)$ & Alcohol content \% of weight & Alcohol content $\%$ of amount & $\mathrm{pH}$ \\
\hline Kadag & 1062 & \multicolumn{2}{|l|}{1038} & 24 & 2.43 & 3.05 & 3.78 \\
\hline Sorvato28 & 1054 & \multicolumn{2}{|c|}{1030} & 24 & 2.45 & 3.08 & 3.50 \\
\hline S28 \& Jerry & 1071 & \multicolumn{2}{|l|}{1039} & 32 & 3.23 & 4.09 & 3.29 \\
\hline $\mathrm{S}_{1}$ & 1063 & \multicolumn{2}{|c|}{1010} & 53 & 5.51 & 6.98 & 3.75 \\
\hline \multicolumn{8}{|c|}{ Table VI: Improved Kable-missin alcohol level } \\
\hline Type of sorghum & $\begin{array}{l}\text { Initial density } \\
(\mathrm{g} / \mathrm{L})\end{array}$ & $\begin{array}{l}\text { Final density } \\
(\mathrm{g} / \mathrm{L})\end{array}$ & \multicolumn{2}{|c|}{$\begin{array}{l}\text { Brix level } \\
\text { of beers }\end{array}$} & Alcohol content $\%$ of weight & Alcohol content \% of amount & $\mathrm{pH}$ \\
\hline Kadag & 1077 & 1026 & \multicolumn{2}{|l|}{51} & 5.23 & 6.57 & 3.60 \\
\hline Jerry & 1058 & 1009 & \multicolumn{2}{|l|}{49} & 5.1 & 6.4 & 3.35 \\
\hline S28 & 1091 & 1039 & \multicolumn{2}{|l|}{52} & 5.25 & 6.66 & 3.70 \\
\hline S28 \& jerry & 1065 & 1018 & \multicolumn{2}{|l|}{47} & 4.45 & 6.14 & 3.41 \\
\hline $\mathrm{S}_{1}$ & 1104 & 1035 & \multicolumn{2}{|l|}{69} & 7 & 8.87 & 4.37 \\
\hline \multicolumn{8}{|c|}{ Table VII: Improved Alcoholic Level of Tchakpalo } \\
\hline Type of sorghum & Initial density $(\mathrm{g} / \mathrm{L})$ & \multicolumn{2}{|c|}{ ) Final density (g/L) } & $D(g / L)$ & Alcohol content $\%$ of weight & Alcohol content $\%$ of amount & $\mathrm{pH}$ \\
\hline Kadag & 1078 & \multicolumn{2}{|c|}{1040} & 38 & 3.84 & 4.83 & 3.14 \\
\hline S28 & 1070 & \multicolumn{2}{|c|}{1042} & 28 & 2.82 & 3.57 & 3.29 \\
\hline Jerry & 1069 & \multicolumn{2}{|c|}{1026} & 43 & 4.4 & 5.54 & 3.10 \\
\hline S28 \& Jerry & 1060 & \multicolumn{2}{|c|}{1023} & 37 & 3.8 & 4.78 & 3.23 \\
\hline $\mathrm{S}_{1}$ & 1091 & \multicolumn{2}{|c|}{1041} & 50 & 5.04 & 6.39 & 3.41 \\
\hline
\end{tabular}


The $\mathrm{pH}$ of beers is 4.35 and 3.14. These values are higher than [10] and [5]; and close to [6]. The $\mathrm{pH}$ values of beers may be due to the activity of antioxidant plants on the bacteria responsible for increasing acidity. At $\mathrm{pH} \mathrm{4}$, the growth of pathogens in food products is inhibited ${ }^{12}$. The acid produced during lactic fermentation lowers the $\mathrm{pH}$ and most microorganisms, including pathogens, are unable to develop in such an environment thus guaranteeing the product's sanitary quality [13;5]. Therefore, these beers would be of good microbiological quality [14]. In addition, the Kablè-missine has higher densities, they are more opaque beers.

\section{Refractometry Method}

The degree Brix of musts and beers and the corresponding alcohol content calculated by the Brewing calculator software (standard deviation 1.04) are recorded in Tables VIII, IX and X.

Table VIII: Alcoholic strength of beer obtained

\begin{tabular}{ccccc}
\hline Sorghum type & Brix degree of the must & Brix level of beers & Attenuation & Alcohol content \%.vol \\
\hline Kadag & 14 & 11 & 35.72 & $2.26 \pm 1,04$ \\
S28 & 12.5 & 8 & 59.38 & $3.72 \pm 1,04$ \\
S28 \& Jerry & 17 & 12 & 49.41 & $4.34 \pm 1,04$ \\
S $_{1}$ & 16 & 6 & 63.75 & $8.47 \pm 1,04$ \\
\hline \multicolumn{4}{c}{ Table IX: Alcoholic strength of improved Kablè-missine } \\
\hline Sorghum type & Brix degree of the must & Brix level of beers & Attenuation & Alcohol content \%.vol \\
\hline Kadag & 17.6 & 10 & 72.24 & $6.58 \pm 1,04$ \\
S28 & 21.5 & 13 & 66.83 & $7.54 \pm 1,04$ \\
Jerry & 11 & 4 & 95.60 & $5.72 \pm 1,04$ \\
S28 Jerry & 15.5 & 8 & 80.21 & $6.39 \pm 1,04$ \\
S & 24 & 13 & 77.58 & $9.86 \pm 1,04$ \\
\hline
\end{tabular}

Table X: Alcoholic strength of improved Tchakpalo

\begin{tabular}{ccccc}
\hline Sorghum type & Brix degree of the must & Brix level of beers & Attenuation & Alcohol content \%.vol \\
\hline Kadag & 18 & 13 & 46.77 & $4.37 \pm 1,04$ \\
Jerry & 16 & 10 & 74.38 & $6.94 \pm 1,04$ \\
S28 & 16.5 & 11 & 55.96 & $4.97 \pm 1,04$ \\
S28 \& Jerry & 15 & 8 & 77.31 & $5.95 \pm 1,04$ \\
S $_{1}$ & 21.1 & 14 & 59.05 & $6.66 \pm 1,04$ \\
\hline
\end{tabular}

Industrial beer

Improved traditional beer

Kablè-missine

Improved Tchakpalo

The physico-chemical characteristics

(density, Brix degree and alcohol content) of the beers depend on the type of sorghum used and the brewing method. Indeed, the beer obtained by the improved traditional method with shade-dried sorvato1 (improved Kablè-missine) had a high density, Brix degree and alcohol content compared to those of sun-dried malts (improved Tchakpalo and laboratory method). This difference would be due to the loss of some enzymes responsible for the transformation of starch into fermentable sugar during drying. According to [15], the physicochemical and sanitary qualities of the malts could be improved by controlled drying in the shell at a temperature between $45-50^{\circ} \mathrm{C}$ for 12 hours. It is then preferable to do a controlled drying.

The analysis of the results shows that among the brewing methods used, the laboratory method is less suitable for the preparation of sorghum beer. The high alcohol content of improved Tchoukoutou is due to the fact that it is not possible to use the laboratory method for the preparation of sorghum beer, since the saccharification stage, during which the remaining starch is transformed into sugar, is absent. The high alcohol content of the improved Tchoukoutou is due to the activity of the antioxidant plants on the microorganisms that degrade fermentable sugars, except for yeast. However, the quality of the beer depends on the type of raw materials used, the malting and brewing conditions.

\section{Comparison of densimetry and refractometry}

Figures 2 and 3 show a comparison of the two methods used for the determination of the alcohol content in sorghum-based beers. Indeed, the two methods used should give the same result. The alcohol values calculated by the densimetric method are not very different from those calculated by the refractometric method. The results in Fig. 2 and 3 show that Sorvato 1 beer has a higher alcohol content. 


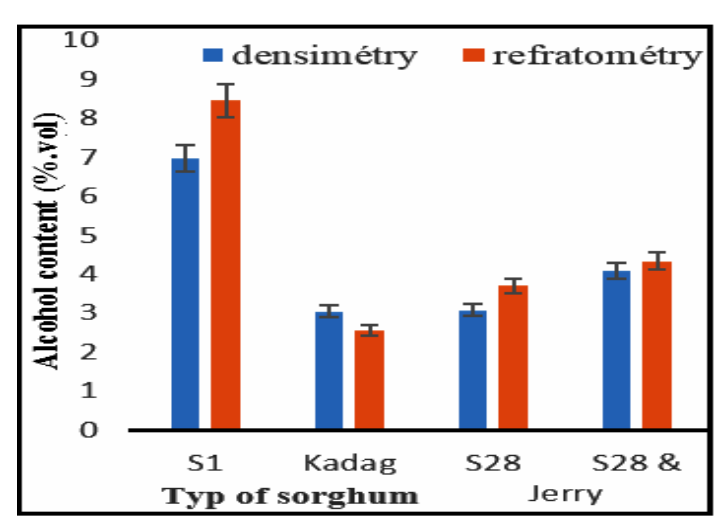

Fig. 2. Alcoholic strength of beers obtained by the laboratory method

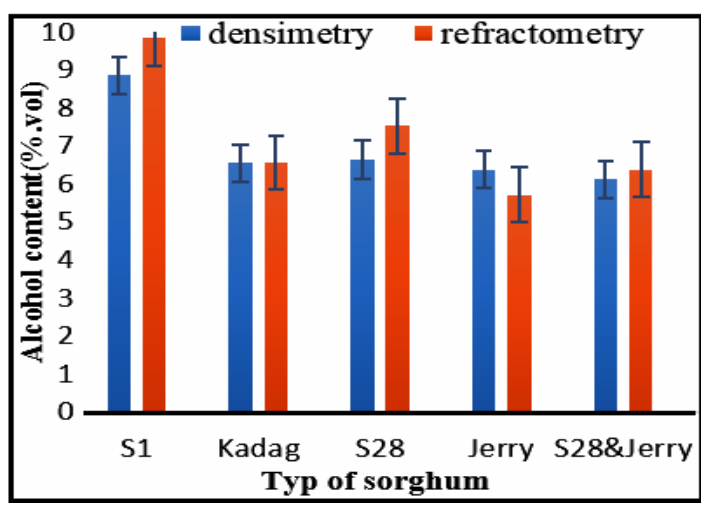

Fig. 3. Alcoholic degree of improved Kablè-missine

Refractometry and densimeter are physical methods that are easy to use. The alcoholic strength values calculated by the densimetric method are not very different from those calculated by the refractometric method. Since the refractometer only takes into account the sugar contained in the solution, refractometry would be the more accurate method than densimetry which takes into account all the dissolved matter in solution. But the densimeter is simple and easier to use. Moreover, it is the most widely used in industrial breweries. Local beer brewers could use it to have a stable beer quality. The alcoholic strength of these beers is close to the alcoholic percentages of industrial beers sold on the Togolese market and those of Tchoukoutou of Lomé analysed by Novidzro and et al., (2019) ${ }^{10}$.

\section{Evaluation of the alcohol content according to the beer preparation process}

The Fig. 4 shows that the beer of Sorvato 1 obtained by the improved traditional method (improved Kablè-missine) is more alcoholic.

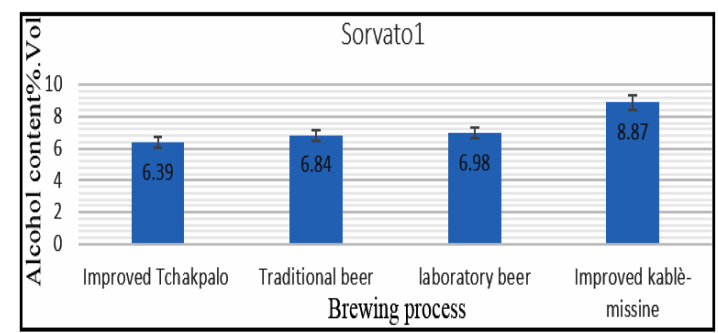

Fig. 4. Evaluation of the alcoholic strength of beers according to preparation methods

The analysis in Fig. 4 shows that beers obtained by adding antioxidant plants followed by controlled anaerobic fermentation have a higher alcoholic strength than beers obtained without adding antioxidant plants and aerobic fermentation; this is because only $S$. cerevisiae yeasts participate in the degradation of sugar in anaerobic fermentation, compared to traditional fermentation, in which other microorganisms in the environment participate in the metabolism of sugar into other compounds, and part of the alcohol formed can also be converted into acetic acid. The effect of antioxidant plants inhibits the activity of these microorganisms. Furthermore, studies on traditional sorghum beers in West Africa show that these beverages constitute a complex biotope composed of several genera and species of yeasts ${ }^{12,15}$. Of which yeasts are the dominant flora ${ }^{16}$. Sorvato 1 produces more alcohol regardless of the brewing method. Sorvato 1 would have contained more fermentable sugars than other sorghums. However, the beers from Kadag and the S 28 \& Jerry blend are more popular. Kadag beer is appreciated. The mixture of Kadag and Sorvato 1 could have a beneficial effect on the quality of the beer.

\section{Study of the stability of the beers obtained}

Beers obtained by adding the leaves of $O$. gratissimum and $V$. amygdalina followed by anaerobic fermentation show that the organoleptic and physicochemical characteristics remained constant after 7 days of fermentation. Moreover, the $\mathrm{pH}$ varied little during the alcoholic fermentation. In contrast to the traditional beers, which showed mould and a very acidic taste from the $4^{\text {th }}$ day of fermentation, this deterioration continued over time. The beers obtained by the improved process 
were stable for at least 10 days and up to four months with no change in characteristics after 7 days of anaerobic fermentation. The leaves of $O$. gratissimum and $V$. amygdalina released certain substances that inhibit the agents responsible for the degradation of sorghum beer quality but do not have an effect on the yeasts. Furthermore, anaerobic fermentation does not allow other microorganisms to participate in alcoholic fermentation. This has a beneficial effect on the organoleptic quality of sorghum beer. These plants have stabilising and antibacterial properties that would guarantee the microbial quality of the beer. Indeed, the antibacterial properties of the essential oil of $O$. gratissimum were reported by ${ }^{17}$ who conducted a study in Kenya on an oil composed of $68.8 \%$ eugenol. This essential oil is active on some Gram-negative bacteria. In Brazil, the antibacterial activity of the essential oil of Ocimum gratissimum against a Gram-positive bacterium (Staphylococcus aureus) and Gram-negative bacteria (Shigella flexineri, Salmonella enteritidis, Escherichia coli, Klebsiella sp, Proteus mirabilis) was also tested by 18 . Furthermore, according to studies by $19, V$. amygdalina has hop-like antibacterial properties and bitterness, which contribute to the production of: methyl salicylate, beta-damascenone and numerous terpenes ( $\delta$ - 3 carene, $\beta$-farnesene, farnesol, $\beta$-citronellol, linalool and 1,8-cineole) in ikigage beer. As in hops, methyl salicylate bound to the glycoside present in $V$. amygdalina could be released during the brewing and fermentation process 20,21 . In addition, linalool and $\beta$ citronellol present in the leaves of $O$. gratissimum and $V$. amygdalina are in the form of glycoside-bound aroma precursors. The results are similar to those of [21 and 11]. V. amygdalina is the possible hop substitute. Of course, these results are only a first step in the search for new and natural antimicrobial products to be offered in the food industry. Further studies must be able to confirm the performances demonstrated in these plants.

\section{CONCLUSION}

This study is a contribution to the improvement of the quality of Tchoukoutou. Many factors influence the quality of the beer, and the fermentation conditions are the most important. They determine the organoleptic quality and the shelf life of the finished product. Anaerobic fermentation results in good quality beer. The addition of Ocimum gratissimum and Vernonia amygdalina leaves followed by anaerobic fermentation allows Tchoukoutou to be stabilised and preserved for at least 10 days after fermentation. Densitometry and refractometry are two simple and easy-to-use control techniques for assessing the alcohol content of Tchoukoutou. Producers of the local beverage can be trained in the use of one of these methods to improve the tasting quality of their beer. Studies are continuing, microbiological analysis will be carried out and other antioxidant plants will be studied to stabilise the local Tchoukoutou beer.

\section{ACKNOWLEDGMENT}

This research did not receive any specific grant from funding agencies in the public, commercial, or not-for-profit sectors.

\section{Conflict of Interests}

The author(s) have not declared any conflict of interests.

\section{REFERENCES}

1. Kayode, A.P. P.; Adegbidi, A.; Hounhouigan, J. D.; Linnemann, A. R.; Robert Nout, M. J. Ecolog. of Food and Nutri., 2005, 44, 271-294,

2. Aholou, C. Hommes migrations., 2010, 1283, 985.

3. Maoura, N.; Mbaiguinam, M.; Nguyen, H. V.; Gaillardin, C.; Pourquie, J. Afri. Sc., 2006, 02(1), 69-82.
4. N'Guessan, F. K.; N'Dri, D. Y.; Camara, F.; World. J. Microbiol Biotech., 2010, 26, 693-699.

5. Aka, S.; Djeni,N ; N'guessan,K.; Yao,K.; Dje, $\mathrm{K}$. Afrique Science: Int $\mathrm{J}$ of $\mathrm{Sc}$ and Tech., 2008, 4, 274- 286.

6. Dahouenon-Ahoussi, E. ; Degnon, R. G.; Adjou, E. S.; Sohounhloue, D. C. K. J of App. Biosc., 2012, 51, 3596-3607. 
7. Konfo, C. T. R.; Chabi, N. W.; DahouenonAhoussi, E.; Cakpo-Chichi, M.; Soumanou, M. M.; Sohounhloue, D. C. K. JMBFS., 2015 , 05, 190-196,

8. Yehouenou, B.; Wotto, V.; Bankole, H.; Sessou, P.; Noudogbessi, J.-P.; Sohounhloue, D. Sc Study \& Research., 2010, 11, 343-351.

9. Konzou, T.; Agbodan, K.A.; Tchani,G.W.; Agbodan, K. M. L.; Boyodé, P. Int Journal of Innovation and Applied Studie., 2020, 29, 628-637.

10. Novidzro, K. M ; Melila,M.; Houndji, B. V. S; Koudouvo, K.; Dotse, K.; Koumaglo, K. H., Int. J. Bio. Chem. Sci., 2019, 12, 2871-2884.

11. Lyumugabe, F.; Gros, J.; Nzungize, J.;
Bajyana, E.; Thonart. P. Biotechnol. Agron. Soc. Environ., 2012, 16, 509-530.

12. Motarjemi Y.; Nout, M. J. R. Bulletin of the $W$ HO., 1996, 74, 553-559.

13. M. J. Torija., Int J Food Micro., 2003, 85, 127-136,

14. Kayodé, A. P. P.; van Boekel,; M. A. J. S ; Nout, M. J. R ; Linnemann, A. R . Open World Cat., 2006.

15. Ballogou, V. Y.; Dossou, J.; de Souza, C. A ; FNS., 2011, 02, 156-161.

16. R. Valyasevi and R. S. Rolle, Int $J$ of Food Microbio., 2002, 75, 231-239.

17. Naumova, E. S.; Korshunova, I. V.; Jespersen, L.; Naumov, G. I. FEMS Yeast Res., 2003, 3, 177-184. 